\title{
The Impact of Crop Mix on Decreasing Soil Price and Soil Degradation: A Case Study of Selected Regions in Czechia (2002-2019)
}

\author{
Zdeňka Gebeltová ${ }^{1}$, Karel Malec $^{1}$, Mansoor Maitah ${ }^{1}{ }^{1}$, Luboš Smutka ${ }^{1}{ }^{\circledR}$, \\ Seth Nana Kwame Appiah-Kubi ${ }^{1, * \mathbb{D}}$, Kamil Maitah ${ }^{1}$, Jeta Sahatqija ${ }^{1}$ and Jitka Sirohi ${ }^{2}$ \\ 1 Department of Economics, Faculty of Economics and Management, Czech University of Life Sciences in \\ Prague, 16500 Prague, Czech Republic; gebeltova@pef.czu.cz (Z.G.); maleck@pef.czu.cz (K.M.); \\ maitah@pef.czu.cz (M.M.); smutka@pef.czu.cz (L.S.); maitahk@pef.czu.cz (K.M.); sahatqija@pef.czu.cz (J.S.) \\ 2 Department of Statistics, Faculty of Economics and Management, Czech University of Life Sciences in \\ Prague, 16500 Prague, Czech Republic; sirohi@pef.czu.cz \\ * Correspondence: appiah-kubi@pef.czu.cz; Tel.: +420-6083-99941
}

Received: 12 November 2019; Accepted: 5 January 2020; Published: 7 January 2020

\begin{abstract}
While the market price of land in Czechia has increased in recent years, the officially set land price, published by the State Land Office and the Research Institute for Soil and Water Conservation, has decreased in several regions (Olomouc, Zlín, South Moravia, Moravian-Silesian, and Central Bohemia Region). Four out of five of these regions are said to have the most fertile soil. The main reason for the official land price decrease has been the re-evaluation of land parcels which are based on field sample testing. Based on these sample tests some parcels have been re-evaluated as less fertile. This paper aims to identify the main determinants, which led to the decrease of the official land price and soil fertility in these regions of Czechia. It has been determined that crop structure significantly differs from the "valuation type structure" which indicates optimal share of individual crops to achieve the optimal yield without soil degradation. It has also been determined that there were statistically significant differences in all selected regions for all observed crops (excluding rapeseed in Moravian-Silesian Region) and Czechia between the shares of individual crops and shares according to the "valuation type structure". It may be concluded that farmers follow short-term interests (profit) instead of long-term goals (soil fertility) in the selected regions. Moreover, results for Czechia suggest that this trend is becoming more common in every region of Czechia. Thus, the Herfindahl-Hirschman Index was utilized. The Herfindahl-Hirschman Index shows decreasing crop diversity in all selected region, as in Czechia as well. Based on the data analysis, it is possible to identify several crops, which are prevailing (wheat, barley, rapeseed, and fodder crops). Three of these crops (wheat, barley, and rapeseed) in combination with intensive farming and poor crop rotation have been found to be problematic and a potential threat which may cause degradation in soil fertility. Based upon this the following measures have been recommended: First, to focus on proven agricultural practices, including crop rotation and fodder crops. Second, the fodder crops production should be supported, and the structure of the "single area payment subsidies" should reflect the negative impact of the three main prevailing crops (wheat, maize, and barley) on soil fertility and the decrease of livestock production in Czechia.
\end{abstract}

Keywords: ESEU; official land price; OLP; valuation type structure; VTS; crop diversity; Czechia

\section{Introduction}

Monitoring soil quality is crucial in terms of the long-term impact that humans have on land. According to Blum [1], soil should be able to fulfil other roles in addition to producing agricultural raw 
materials, including functions such as: biomass production, human and environmental protection, gene reserves, the physical basis of human activities, a source of raw materials and geodetic and cultural heritage. The very same issue is being addressed in other countries as well; for example, in Switzerland, this was specifically studied by Desaules et al. [2]. The authors presented an overview that lists specific threats affecting the soil fund. Further, Fließbacha et al. (2007) [3] compare the impact of organic and conventional farming on agriculture in Canada, Arshard et al. [4] addresses the assessment of the quality of agricultural land by describing the key indicators and the procedure of monitoring changes in the quality of land resources. Obade [5] states proposes a soil assessment concept that integrates the soil's physical and chemical properties into the Soil Quality Index (SQI) in the United States. In addition, the author uses the index to evaluate the changes in soil quality in relation to crop yields during two growing seasons.

Over the past three decades, the European Union attention has been focused on assessing the impact of intensive agriculture on the environment and food safety [6]. As such, it has been confirmed that intensive use of land has a direct effect on food production levels, drinking water quality, food and plant and animal space [7]. Lambin et al. [8] strongly emphasizes this by highlighting that scenario models for future land use exist; this confirms the overuse of land especially in industrial zones.

According to the Czech Ministry of Agriculture, soil fertility is often influenced by the choice of growing technologies and crop rotation [9]. As such, certain crops leave soil conditions better than they were before its sowing or planting [10]. In addition, Wischmeier et al. [11] draw attention to agro-technical practices as well as the importance of protecting cultivated crops considering that every $10 \%$ increase in soil coverage (number of plants per $\mathrm{m}^{2}$ ) reduces soil erosion by $20 \%$. Šoltysová [12] confirm the negative changes in the physical characteristics of alluvial soil by formation of anthropogenic soil, which is mainly related to the soil management system and types of crops, included in the crop rotation (field stationary experiment over 25 years). The author further explains that factors which negatively influence soil structure and quality include: soil compaction, changes in hydrothermal conditions due to excessive irrigation, monoculture cultivation with the same plowing depth or high doses of potassium mineral fertilizers. According to the Ministry of the Environment of Czechia, $\mathrm{Ca}$ and $\mathrm{Mg}$ are extracted from the soil by primarily using cereals, for example, without perennial fodder crops [9]. Reference [13] focuses on exploring the reduction of crop diversity and the need to eliminate negative consequences caused by crop homogeneity considering that the species composition of basic cereals and other crops had been considerably more balanced in the past. In 2018, the author delves further by adding that the current changes reflect changing dietary habits and farmers' economic motivation.

Czechia is in an area where high quality soil known as "chernozem" can be found, specifically in Northwest Bohemia and South Moravia. In addition to the Czechia, this type of soil can also be found in Slovakia (Danubian Lowland), central Germany, Hungary, Eastern Romania, and Northern Bulgaria [14]. The area and production capacity of high-quality agricultural soils is decreasing, and the share of erosion-endangered soils is increasing [14,15].

The responsible authority for monitoring the soil quality in Czechia is the State Land Office (SLO) and The Research Institute for Soil and Water Conservation (RISWC); whereas, the soil fund is recorded in the cadastre and in Land Parcel Identification System (LPIS) database and each patch of land has a so called "evaluated soil ecological unit" (ESEU) code, also called BPEJ in Czech. (Sentence is really confusing) This five-digit number reflects the information on the soil characteristics [16]. The information on ESEU codes are represented in Table 1. 
Table 1. "Evaluated soil ecological unit" (ESEU) codes.

\begin{tabular}{cccc}
\hline ESEU (BPEJ) Code & Digit Order & & Scale \\
\hline X.xx.xx & 1. & Climatic Region Code & $0-9$ \\
x.XX.xx & 2. and 3. & Code of main pedelogic unit & $01-78$ \\
X.xx.Xx & 4. & Code of slope and exposure & $0-9$ \\
x.xx.xX & 5. & Associated code of stoniness and soil depth & $0-9$ \\
\hline
\end{tabular}

Czechia is divided into 14 regions and the soil characteristics can be determined based on the ESEU codes for every individual region. There are also stated the Official Land Price (OLP) for individual cadastral territories (municipalities) [18]. The Official Land Price is stated according to ESEU code, which indicates the main soil characteristics. The Institute of Agricultural Economics and Information [19] which places attention on basic and applied research and development in the field of agricultural economics and based on that provides advice to the farmers, and professional and international organizations. Němec [19] developed "Valuation type structure" (VTS)" which in Czech is also known as OTS. This valuation type structure can be used for institution and research to determine the land price according to the future yield and profit. The VTS includes the recommended structure of crops for each ESEU codes, which reflect the main land characteristics. This recommended structure is a mix of the suitable crops for the given type of land and should ensure the balance between the yield and sustainable soil quality [19]. Based on the given ESEU code and its valuation type structure, it is possible to calculate the so called "gross annual rental effect" (HRRE) which assess the economic potential of soil. HRRE is the difference between the amount of yield per 1 ha and the costs of inputs. Based on this, the Official Land Price can be obtained. The Official land price also reflects the soil quality and can be used for soil qualitative changes evaluation as it is based on ESEU [18].

Evidence has shown decreasing land prices for several regions in Czechia [20]. The reported decrease of HHRE in given regions corresponds with the regions which have the highest soil quality, except those in the Moravian-Silesian region, Reference [21] see the Table 2. Reference [21] this trend was also confirmed for the period 2009-2018 in the same regions for official land prices by [22]. The recorded decrease in official land price, as the potential yield (and the soil quality) are caused by soil degradation.

Table 2. "Gross annual rental effect" (HRRE) changes 2008-2011 in CZK/ha.

\begin{tabular}{cc}
\hline Region & HRRE Change (CZK/ha) \\
\hline Zlín & -763 \\
Vysočina & 111 \\
Olomouc & -327 \\
Central Bohemia & -194 \\
South Moravian & -907 \\
Liberec & 321 \\
South Bohemian & 46 \\
Pilsen & 58 \\
Hradec Králové & 221 \\
Pardubice & 218 \\
Moravian-Silesian & -227 \\
Usti nad Labem & 78 \\
Karlovy Vary & 352 \\
\hline$\quad$ Source: Reference [16,20].
\end{tabular}

RISWC and SLO test the soil samples in selected land parcels of cadaster and research if the soil quality corresponds with the ESEU code. If a difference is found, the given parcel of land is re-evaluated by different ESEU codes which also leads to the re-evaluation of the Official Land Price [23]. The yield as the crop prices are increasing, so the decreasing OLP shows on the decreasing soil quality. One of 
the possible factors may be intensive farming, which is prevalent in Czechia. Most farmers also farm on the rented land and the average area per one farm is the biggest in the EU. Thus, the conflict between the short-run (profit) and long-term (sustainable soil fertility) is mentioned in Czechia and other post-Soviet countries [24]. These facts are widely discussed as Czechia has witnessed a period of drought [25] According to Edwards et al. [26] the cropping pattern and crop rotation play a key role for the soil fertility.

\section{Objectives}

Based on statistical analysis and diversity indices to determine the main trends which led to the OLP decrease in the selected regions.

The following sub-objectives were stated to be able to better achieve the main objective:

- Determine the structure of 10 of the most widespread crops according to VTS for regions where the OLP has decreased.

- Identify differences between the VTS crop share and real shares of crops in the regions where the OLP has decreased and to determine if these differences are statistically significant (at level $\alpha=0.05$ ).

Accordingly, the following hypotheses were tested:

Hypothesis 1 (H1). There is no statistically significant difference between the expected (VTS) and observed (Czech statistical office) structure in selected regions as neither in Czechia.

Hypothesis 2 (H2). There is no statistically significant difference between VTS and CSO for shares of individual crops in selected regions and Czechia.

\section{Materials and Methods}

\subsection{Data}

This research is based heavily on the data published by the Czech Statistical Office (CSO), and EU Statistical Office (EUROSTAT). It is important to emphasize that the data is derived from information based on the agricultural land registered at the public register of Land Parcel Identification System (LPIS) on which primary agricultural production is utilized. The farm land which is reported by LPIS is eligible for subsidies as e.g., single area payments schemes (SAPS) or the rural development programme (RDP). The land reported in the LPIS has an area of 3557597 hectares in Czechia [27]. According to The Czech Office for Surveying, Mapping and Cadastre (COSMC) [28] it accounts for $84.9 \%$ of total agricultural land in the Czechia.

The authors worked with ESEU codes (Evaluated Soil Ecological Units, in the Czechia known as BPEJ. ESEU includes factors such as climate conditions, stoniness, soil depth etc. ESEU codes of land reported by LPIS were used. There are 2199 different ESEU codes and LPIS dataset consists of 1954 codes [27]. The ESEU database is primarily developed and administered by the Research Institute for Soil and Water Conservation (RISWC) and State Land Office (SLO).

The research is based on valuating type structures (VTS) carried out by the Institute of Agricultural Economics and Information (IAEI) [19]. These VTS provide information about the percentage representation (i) of crops $(k)$ in the individual type structures $(n)$. The VTS are used for the economic evaluation of ESEU potential [29]. The objective of valuation type structure is not to order the crop structure to the farmers, but to represent the most suitable share of the ten main crops (in \%) for the given soil type and climatic region represented by ESEU code. VTS indicate the types of most suitable crops for given soil type, so that their cultivation in the selected location should bring the highest productivity and keep the soil quality at the same level [30]. A significant source of data is the information of the assigned ESEU codes (<2000 codes) in 38 VTS [29]. The structure of VTS has not recorded significant changes over the last decade as the main soil characteristics are consistent [27]. 
The research will also utilize the Czech Statistical Office [28] public database; the statement of crops sowing areas (code: ZEM03A/3) and the statement of cultivated agricultural land (code: ZEM03B/3). The statements contain annual data of the use of agricultural land to the level of individual regions up until 31 May 2019 [28]. The real representation of crops on the sowing areas will be calculated. The data about sowing areas for regions have been available since 2002, as the CSO database was damaged by floods in 2002. The data for all of Czechia have been available since 1993, when Czechia was established. From these reasons the changes in the selected regions were studied for the period of 2002-2019 and the trend for all of Czechia uses the longer time series (1993-2019).

\subsection{Methods}

The VTS were selected according to the ESEU codes in regions where the official land price decreased in 2009-2018. The VTS for Czechia was selected for comaprison as well. Based on the VTS, the share was calculated for the optimal mix of crops for the given region. This optimal structure was compared with real crops distribution.

Areas of individual ESEU (in $\mathrm{m}^{2}$ ) in LPIS database are determined by using ArcGIS software. The layers representing the soil blocks were divided according to the individual regions in Czechia and based on these parts the total area for individual ESEU codes in given regions were calculated.

The percentage share of 11 crops was calculated (10 crops on arable land and then VTS separately on agricultural land) in the regions of the Czechia (and all Czechia). The average percentage normative percentage share $(r)$ of crop $(k)$ in all concerned VTS $(n)$ were calculated by the weighted arithmetic mean of all normative shares of crops in TCS (i). The weight was the area of VTS in ha $(x)$. The normative representation $(r)$ of crops $(i)$ was calculated for the selected regions and then for all of Czechia:

$$
r_{(k)}=\frac{\sum_{n=1}^{N}(x \times i)}{\sum_{n=1}^{N}(x)} \times 100 \%
$$

where:

$r=$ average proportion of crop (i) in all VTS, $r \in(0,100)$.

$k=$ crops in individual VTS, $k \in(1,11)$.

$n=$ valuation type structure (VTS), $n(1,40)$.

$x=$ area of VTS depending on areas included in ESEU.

Then the percentage share of individual crops according to the VTS and the real crop structure were compared. The tested hypotheses were about the existence of statistically significant differences for expected and the real crop distribution in the individual regions. The Chi-squared test goodness of fit was used.

In order to determine the deviations of observed crop distribution from their expected shares, a Chi-square test approach was conducted. This is in line with Pearson [31] who confirmed that the Chi-square approach is a better model to determine how a variable(s) observed values defer from the expected. In view of this article's objectives, the Chi-square formula below was used:

$$
X^{2}=\sum_{i=1}^{k} \frac{\left(X_{i}-E p_{i}\right)^{2}}{E p_{i}}
$$

where:

$X^{2}=$ Chi-square value.

$X_{i}=$ Observed crop share in each category.

$E p_{i}=$ Expected crop share in each category. 
Hypothesis 3 (H3). There is no stastically significant difference between the expected (VTS) and observed (CSO) values at the level $\alpha=0.05$.

The Chi-square test was conducted for ten crop shares (categories) namely fodder crops, maize, permanent grasslands, barley, oat, potatoes, rapeseed, rye, sugar beet, and wheat. The Chi-square is tested against the Null and Alternative Hypothesis.

To test the differences between the VTS structure and the real areas for individual crops in the given regions, the one sample test of proportion was used:

$$
Z=\frac{\hat{\pi}-\pi_{0}}{\sqrt{\frac{\pi_{0}\left(1-\pi_{0}\right)}{n}}}
$$

where:

$\hat{\pi}=$ sample proportion.

$\pi_{0}=$ tested hypothesis proportion.

$n=$ sample size.

Hypothesis 4 (H4). There is no stastically significant difference between the individual crop share (CSO) and $V T S$ share in given region at the level $\alpha=0.05$.

The average change of sowing areas of individual crops in selected regions in period of 2002-2019 was calculated based on the following formula:

$$
\varnothing \Delta Y_{i}=\frac{\sum Y_{i t} / Y_{i t-1}}{m}
$$

where:

$\varnothing \Delta Y_{i}=$ Average annual chain index.

$Y_{i t}=$ Share of individual crop $(i)$ at total area in given year.

$m=$ number of observed years.

To assess the crop diversity structure, the Herfindahl-Hirschman Index (HHI) was used. The Herfindahl-Hirschman Index is a measurement used to understand the level of competition that exists within a market or industry, as well as give an indication of how the distribution of market share occurs across the companies included in the index HHI is a widely accepted measure of concentration used by biologists, ecologists, linguists, economists, sociologists, and demographers. For instance, the U.S. Department of Justice and the Federal Reserve Board use it to evaluate the competitive effects of mergers [32].

The formula for determining $\mathrm{HHI}$ is as follows:

$$
H H I=\sum_{i=1}^{m}\left(M S_{l}\right)^{2}
$$

where:

$M S_{l}=$ the percentage share of total area 1 and there are $\mathrm{m}$ crops in the regions.

The resulting numerical value can be as high as 10,000 (indicating a high concentration and little diversity) or as low as share would have an HHI of 100.

\section{Results}

Statistical data on the use of agricultural land in Czechia over the last 25 years confirms the long-term tendency of decreasing species diversity of agricultural crops, as per Figure 1 . The share of 
the two most widespread crops i.e., wheat and barley in Czechia's total sowing area in 2018 reached $50.0 \%$, which is an increase of 5.3 p.p. compared to 1993 . The share of the three most widespread crops i.e., wheat, barley, and oilseed rape in the same period increased from $50.0 \%$ to $63.2 \%$ (i.e., an increase of 13.2 p.p.). Differences in the monitored period are in wheat (+8.7 p.p.) and in rapeseed (11.5 p.p.) [28].

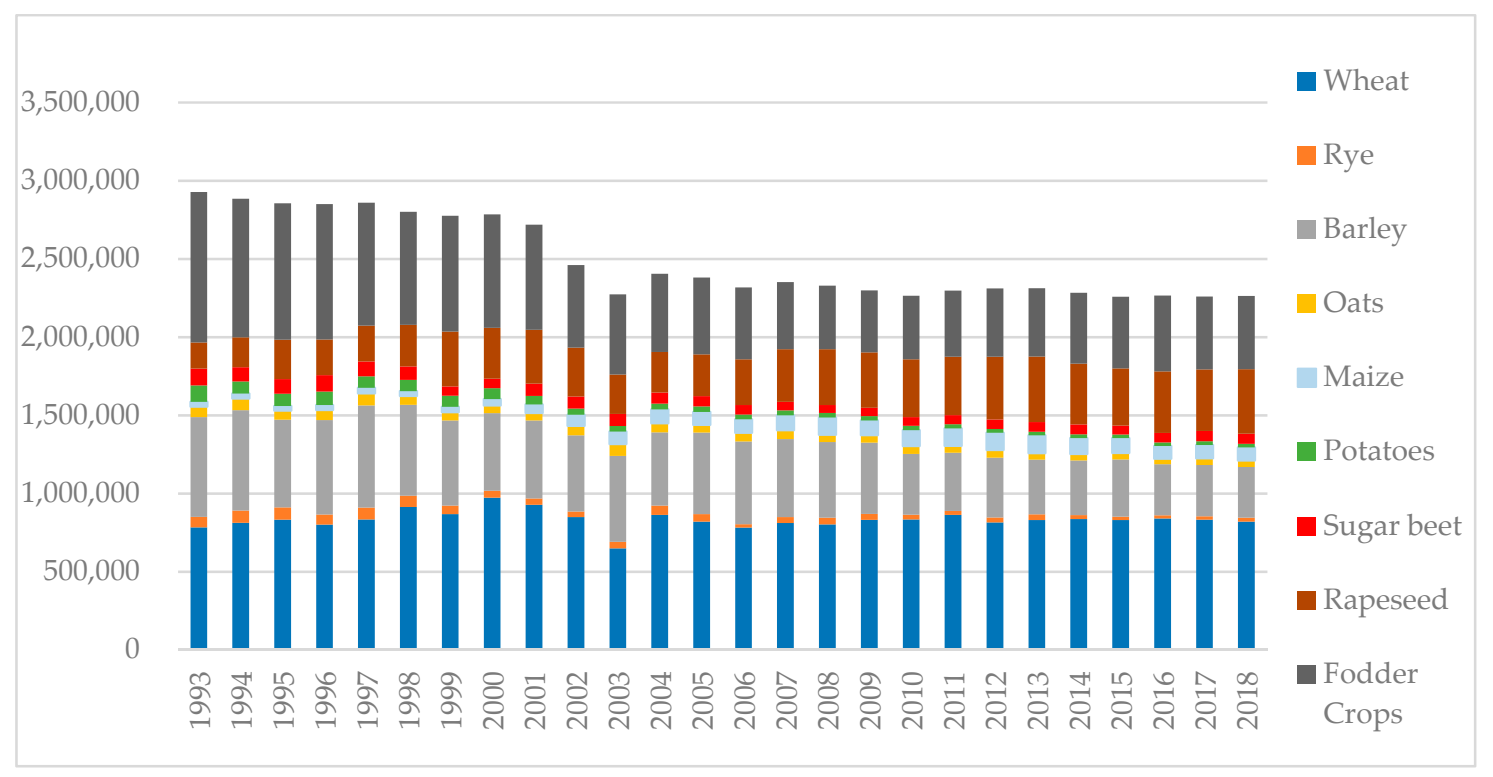

Figure 1. The evolution of the crop structure of selected crops in Czechia (1993-2018) in hectares, Source: [28].

Formula (4) is used as a basis for the calculation of the average annual changes in the selected regions based. The results are represented by Figure 2. In the regions explored, an increase in the shares of wheat (from $0.39 \%$ up to $1.51 \%$ ), rye (from $2.89 \%$ up to $39.61 \%$ ), rapeseed (from $1.54 \%$ up to $4.72 \%$ ), and permanent grasslands (from $0.52 \%$ up to $1.97 \%$ ) was reported. The highest average positive annual change was reported for rye sowing areas in the Zlín region $(39.61 \%)$, but the share of rye in the total observed area (arable land + permanent grasslands reported in LPIS database) was only $0.32 \%$ in 2019.

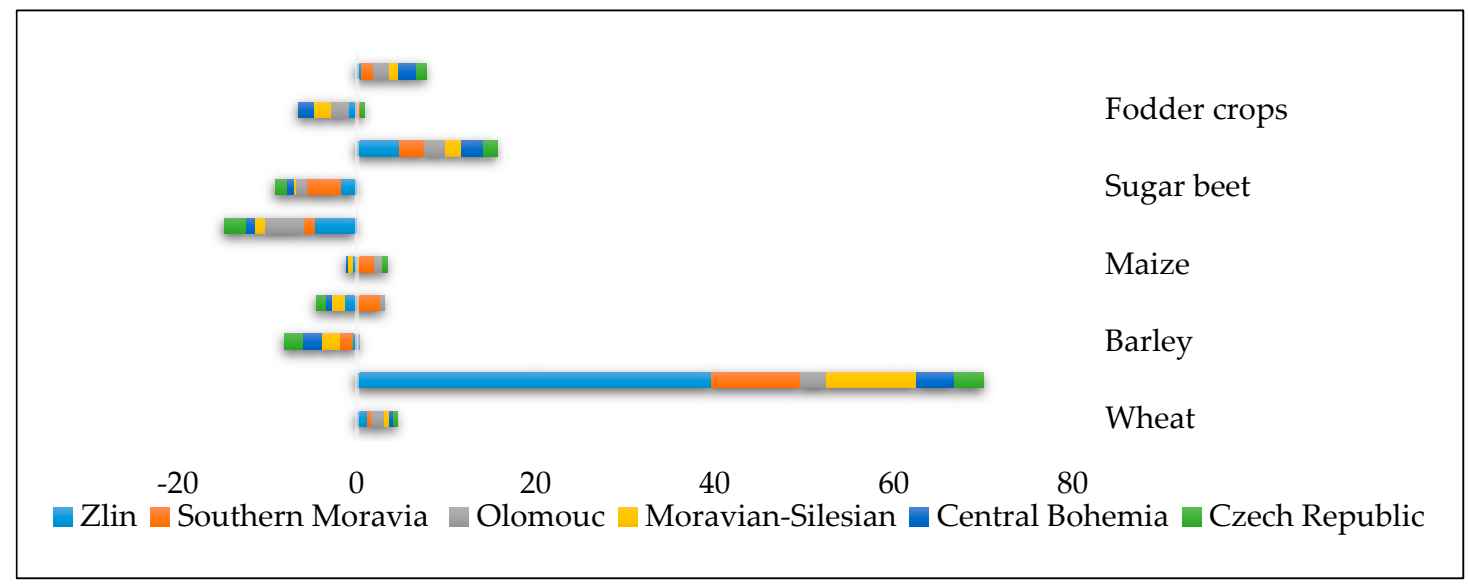

Figure 2. Average annual change for individual crops in selected regions 2002-2019, Source: Authors, based on CSO [28].

Decreasing shares were reported in all selected regions for potatoes (from $-4.74 \%$ up to $-1.02 \%$ ) and sugar beets (from $-3.84 \%$ up to $-0.16 \%$ ). The biggest negative average annual change was recorded in the Zlín region for potatoes sowing area (-4.74\%). Barley $(-2.12 \%$ up to $0.27 \%)$, oats $(-1.51 \%$ up to $2.65 \%$ ), maize (form $-0.53 \%$ up to $1.93 \%$ ), and fodder crops decreased in most regions 
(from $-2.1 \%$ up to $0.44 \%)$. This was in contrast to the Olomouc region, where barley $(+0.27 \%)$, oats $(+0.45 \%)$, maize increased $(+0.93 \%)$, Southern Moravia region where increased oats $(+2.65 \%)$, maize $(+1.93 \%)$, and fodder crops $(+0.44 \%)$, and Czechia where the area of fodder crops $(+0.38 \%)$ and maize increased $(0.57 \%)$.

Table 3 shows the differences in the share of real cultivated crops (\%) in comparison with the representation of crops according to Reference [6] in Reference [27].

Table 3. Crop shares comparison between the "Valuation type structure" (VTS) and real crop distribution (k) in 2018.

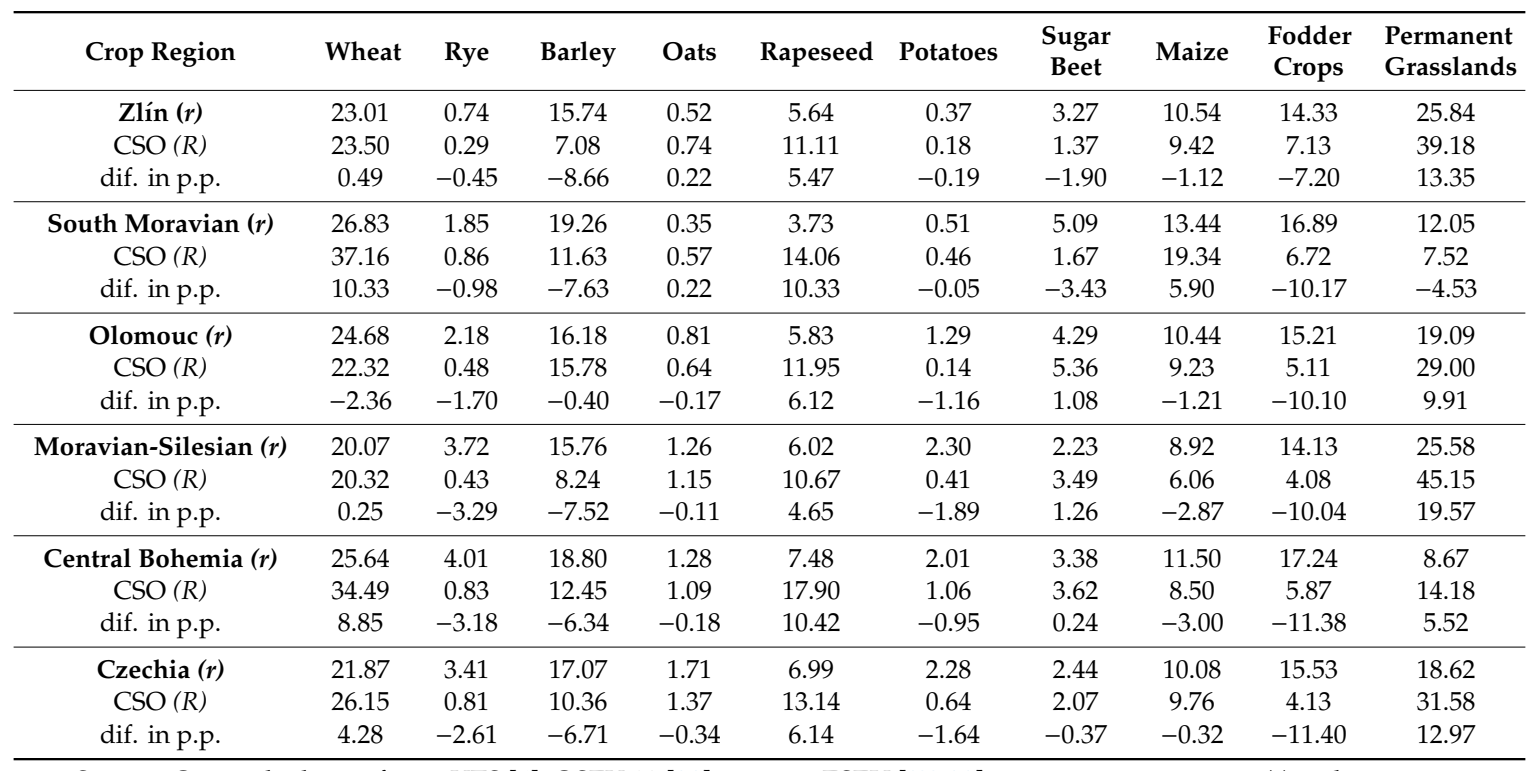

Source: Own calculation from: VTS [6], OSEV-03 [28], acreage ESEU [27-33], p.p. = percent points. $(r)$ is the average normative representation of the crop (i) according to VTS (in $\%)$. $(R)$ is a real share of individual crops (\%).

Table 3 clearly shows that the optimal structure based on VTS methodology does not correspond with the real crop distribution in the selected regions. There are negative differences indicating that the share of the given crop is lower than the VTS structure. These negative differences are observed in all selected regions in the case of rye $(-3.29 \%$ up to $-0.45 \%)$, barley $(-8.66 \%$ up to $-0.4 \%)$, potatoes $(-1.89 \%$ up to $-0.05 \%)$, and fodder crops ( $-11.40 \%$ up to $-7.20 \%)$. The positive differences were recorded in all of the regions for rapeseed ( $+4.65 \%$ up to $10.42 \%)$ and permanent grasslands ( $+5.52 \%$ up to $19.57 \%)$, in exception of South Moravian region $(-4.53 \%)$. The opposite values were observed for maize shares, which are negative for all regions $(-3.0 \%$ up to $-0.32 \%)$, except the South Moravian region $(+5.9 \%)$. Wheat recorded positive differences in all the selected regions ( $+0.25 \%$ up to $10.33 \%)$ except for the Olomouc region, where a negative difference was recorded $(-2.36 \%)$. Oats had positive differences in Zlín $(0.22 \%)$, and the South Moravian $(0.22 \%)$ regions. There were recorded negative differences for oats in Olomouc $(-0.17 \%)$, Moravian-Silesian $(-11 \%)$, Central Bohemia $(-0.18 \%)$ regions, and $(-0.34 \%)$ in Czechia as a whole. Sugar beets were lower than VTS in Zlín (-1.9\%), South Moravian $(-3.43 \%)$ regions, and in all of Czechia $(-0.37 \%)$. The higher share of sugar beets were recorded in Olomouc $(+1.08 \%)$, Moravian-Silesian $(+1.26 \%)$, and in the Central Bohemia $(+0.24 \%)$ regions.

According to these differences the Chi-square goodness of fit test has been conducted to test the null hypothesis about no existence of statistically significant differences between the VTS and real crop structure at the level $\alpha=0.05$. The results are represented in the Table 4 . 
Table 4. Chi-square goodness of fit test-differences between the VTS and real crop structure.

\begin{tabular}{ccccccc}
\hline \multicolumn{7}{c}{ Chi-Square Test for Specified Proportions in Given Regions } \\
\hline Region & Zlin & $\begin{array}{c}\text { South } \\
\text { Moravian }\end{array}$ & $\begin{array}{c}\text { Olomouc } \\
\text { Region }\end{array}$ & Moravian-Silesian & $\begin{array}{c}\text { Central } \\
\text { Bohemia }\end{array}$ & $\begin{array}{c}\text { Czech } \\
\text { Republic }\end{array}$ \\
\hline Chi-Square & $27,729.8$ & 253,230 & $38,954.42$ & $61,421.75$ & $11,3267.2$ & $820,748,5$ \\
DF & 9 & 9 & 9 & 9 & 9 & 9 \\
Pr > ChiSq & $<0.0001$ & $<0.0001$ & $<0.0001$ & $<0.0001$ & $<0.0001$ & $<0.0001$ \\
Chi (DF9) alfa 0.05 & 16.919 & 16.919 & 16.919 & 16.919 & 16.919 & 16.919 \\
alfa & 0.05 & 0.05 & 0.05 & 0.05 & 0.05 & 0.05 \\
Sample Size & $142,783.08$ & $304,467.44$ & $229,843.01$ & $196,631.17$ & $494,303.88$ & $3,134,794.07$ \\
\hline
\end{tabular}

Source: Authors based on IAEI and CSO [28].

According to Table 5, the null hypothesis with regard to the lack of differences between the VTS and real crop structure was rejected in all selected regions and in Czechia as a whole. A statistically significant differences at the level $\alpha=0.05$ for all selected regions is existent.

Table 5. One sample test of proportion—differences between VTS and real share of individual crops.

\begin{tabular}{|c|c|c|c|c|c|c|c|c|c|c|c|}
\hline Region & Fodder Crops & Maize & $\begin{array}{l}\text { Pernanment } \\
\text { Grasslands }\end{array}$ & \multicolumn{2}{|c|}{ Barley } & Oats & Potatoes & Rapeseed & Rye & $\begin{array}{c}\text { Sugar } \\
\text { Beet }\end{array}$ & Wheat \\
\hline \multirow{3}{*}{ Zlin } & $\%$ & 0.1 & 0.1 & 0.4 & 0.1 & 0.0 & 0.0 & 0.1 & 0.0 & 0.0 & 0.2 \\
\hline & Test \% & 0.1 & 0.1 & 0.3 & 0.2 & 0.0 & 0.0 & 0.1 & 0.0 & 0.0 & 0.2 \\
\hline & Statistics u & -221.6 & 22.8 & 263.0 & -246.7 & 160.7 & -194.8 & 268.4 & -231.5 & -227.0 & 10.5 \\
\hline \multirow{3}{*}{$\begin{array}{l}\text { South } \\
\text { Moravian }\end{array}$} & $\%$ & 0.1 & 0.1 & 0.1 & 0.1 & 0.0 & 0.0 & 0.2 & 0.0 & 0.0 & 0.4 \\
\hline & Test \% & 0.2 & 0.1 & 0.1 & 0.2 & 0.0 & 0.0 & 0.0 & 0.0 & 0.1 & 0.3 \\
\hline & Statistics u & -103.6 & 11.0 & -64.7 & -92.3 & 26.4 & -3.7 & 1054.9 & -27.9 & -50.4 & 177.0 \\
\hline \multirow{3}{*}{ Olomouc } & $\%$ & 0.1 & 0.1 & 0.3 & 0.2 & 0.0 & 0.0 & 0.1 & 0.0 & 0.1 & 0.2 \\
\hline & Test \% & 0.2 & 0.1 & 0.2 & 0.2 & 0.0 & 0.0 & 0.1 & 0.0 & 0.0 & 0.2 \\
\hline & Statistics u & -84.9 & 26.8 & 165.7 & -5.6 & -8.1 & -16.2 & 90.2 & -26.5 & 28.9 & -28.8 \\
\hline \multirow{3}{*}{$\begin{array}{l}\text { Moravian- } \\
\text { Silesian }\end{array}$} & $\%$ & 0.0 & 0.1 & 0.5 & 0.1 & 0.0 & 0.0 & 0.061 & 0.0 & 0.0 & 0.2 \\
\hline & Test \% & 0.1 & 0.1 & 0.3 & 0.2 & 0.0 & 0.0 & 0.060 & 0.0 & 0.0 & 0.2 \\
\hline & Statistics u & -74.2 & 31.2 & 306.3 & -72.1 & -4.2 & -24.0 & 0.8 & -26.6 & 47.9 & 3.1 \\
\hline \multirow{3}{*}{$\begin{array}{c}\text { Central } \\
\text { Bohemia }\end{array}$} & $\%$ & 0.1 & 0.2 & 0.1 & 0.1 & 0.0 & 0.0 & 0.1 & 0.0 & 0.0 & 0.3 \\
\hline & Test \% & 0.2 & 0.1 & 0.1 & 0.2 & 0.0 & 0.0 & 0.1 & 0.0 & 0.0 & 0.3 \\
\hline & Statistics u & -135.7 & 187.1 & 184.3 & -103.2 & -11.1 & -35.0 & 30.2 & -53.0 & 9.8 & 191.7 \\
\hline \multirow{3}{*}{$\begin{array}{c}\text { Czech } \\
\text { Republic }\end{array}$} & $\%$ & 0.0 & 0.1 & 0.3 & 0.1 & 0.0 & 0.0 & 0.1 & 0.0 & 0.0 & 0.3 \\
\hline & Test \% & 0.2 & 0.1 & 0.2 & 0.2 & 0.0 & 0.0 & 0.1 & 0.0 & 0.0 & 0.2 \\
\hline & Statistics u & -312.7 & 216.6 & 851.0 & -270.1 & -41.9 & -104.3 & 235.7 & -125.7 & -39.6 & 226.8 \\
\hline
\end{tabular}

Source: Authors based on IAEI and CSO [28].

The one sample test of proportion has been used to test if there is a statistically significant difference for individual crops in selected regions at the level of $\alpha=0.05$. The results are described in Table 5.

The results of one sample test for proportion suggest that it is possible to reject the null hypothesis about the non-existing difference between the real share of individual crops and VTS share in all cases at the level $\alpha=0.05$. The only exception is in the case of rapeseed in the Moravian-Silesian Region, where the null hypothesis cannot be rejected at the level of $\alpha=0.05$.

As such, the results suggest that farmers do not take the VTS crop structure into account, as they are motivated by different factors. It is possible to assume that the main decision-making factor is profit, not maintaining soil quality and at the same time taking into consideration that the main factor affecting the soil quality is the crop diversity. Based on this line of thought, the Herfindahl-Hirschman Index was calculated for the period 2002-2019. The results are described in Figure 3.

The HHI index in Figure 3 shows decreasing crop diversity in all regions. The values around 2000 indicate high diversification, but it is important to note that the agricultural sector and commodity markets are generally considered to be closed to the perfect competition (homogenous product, lot of producers) [34]. The decreasing trend of diversity (increasing HHI values) is obvious in all previously mentioned regions. The highest crop diversity decrease is reported in Moravian-Silesian Region. 


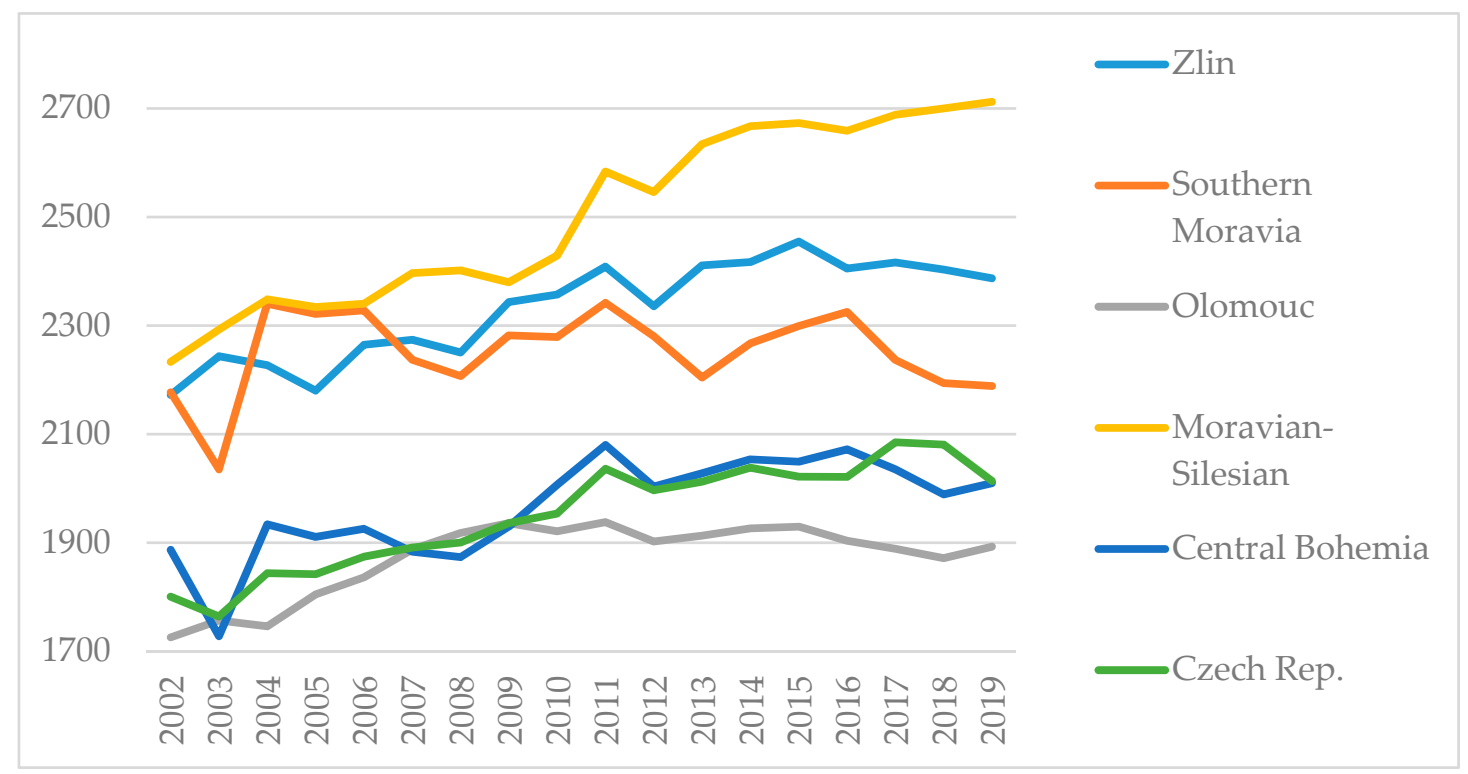

Figure 3. The Evolution of the Herfindahl-Hirschman Index in the selected regions between 2002 and 2019, Source: Authors based on CSO data [28].

The decreasing trend of crop structure diversity is also represented in Figure 1 where date on crop production within the timeline of 1993-2018 for the whole of Czechia is displayed. There are three main commodities which occupied from $88.4 \%$ (in 2003) up to $93.34 \%$ (in 2013) of the total arable land.

Based on the data shown, one can conclude that the trends highlighted above for individual regions work also for Czechia as a whole. Yet negative changes have been discovered in the selected regions (Zlín, South Moravia, Central Bohemia, Moravian-Silesian, and Olomouc Region) but according to the above described trend the other regions may follow suit.

\section{Discussion}

Rapeseed is grown on $16.7 \%$ of the arable land registered in LPIS [27]. This share was $5.26 \%$ of the total sowing area in 1993. The confrontation of normative (VTS) and real crop representation (Table 3) in LPIS shows that the area of rapeseed in Czech fields has increased by 6.14 p.p. In the region with the highest soil quality (Southern Moravian Region), rapeseed growing is higher by 9.3 p.p. (more than 250\%). In other regions rapeseed areas are more than double (in comparison with the calculated proportion according to the "valuation type structure"). Rapeseed has become a very profitable crop and there is high demand on the market as it is used for fatty acid methyl ester (FAME) production. Research confirms that rapeseed is a crop which can be planted in relatively salty and sodium rich soils [35] but its long-term monoculture cultivation threatens the landscape ecosystem and soil structure [13-36]. The Czech Union of Growers and Processors of Oilseeds or the Agrarian Chamber of Czechia are convinced that the share of rapeseed growing in Czechia is not exceptionally high and support of its production is necessary [37]. In the EU context when compared to other members, Czechia holds a relative primacy when it comes to oilseed rape cultivation, $(16.0 \%$ of sowing areas) followed by Slovakia (11.5\%), Germany (10.4\%), France (8.6\%), Hungary (7.9\%), Poland (7.7\%), and Switzerland (5.7\%) [6].

The share of wheat on arable land is increasing slightly each year and its representation is $20 \%$ higher than the normative (VTS) value. Wheat is considered a deteriorating crop for soil quality especially after harvesting, when large amount of nutrients is taken away from the soil. The intensive farming of wheat leads to decreasing microbial diversity and potential yield of soil [38]. On the other hand, wheat can be easily stored, and wheat market has high liquidity (high supply and demand). Maize is also considered to be a high erosion crop [39]. 
Its cultivation method should be under the supervision of an agro-technical specialist. The real extent of maize cultivation is greater than the VTS indicate (+5.90 p.p.) in the South Moravia region, which is considered to have the highest soil quality [21]. The importance of growing corn has increased in Czechia in the last ten years in connection with the production of bioethanol; 39.6\% of the total amount of bioethanol produced in 2016 was produced from maize [9]. Maize has a relatively good production yield of ethanol $(3.8 \mathrm{hl} / \mathrm{t})$ compared to the more frequently used sugar beet $(1.07 \mathrm{hl} / \mathrm{t})$. Increased maize production is also associated with: (a) increasing use of maize as a feed, (b) as seed, including seed for silage maize (import of maize has been reduced and maize is also exported to the other countries) [40].

There is a low share of fodder cultivation on LPIS registered arable land (roughly 2-3 times lower than VTS indicate). The negative differences between the fodder crops according to the VTS and CSO have been found in all selected regions. Fodder crops help prevent erosion [41]. In addition, [42] recommends to plant fodder crops especially in highland areas, which are more threatened by erosion. In Moravian-Silesian Region, where the risk of water erosion is the highest from selected regions, the share of fodder crops is $4.08 \%$, which is more than 10 p.p. less than $14.13 \%$ as indicated by VTS. A decreasing share of fodder crops on arable land significantly reduces their soil-protective function. Forage production corresponds to the development of gross agricultural animal production. Research suggests that the share of livestock production in total agricultural production is decreasing [43]. To preserve the state of the landscape fodder crops should be harvested two or three times a year. If it is not possible to use the produced biomass for feeding, then it is possible to use it for non-feeding purposes, such as biogas production.

The extent of potato cultivation is also decreasing ( $R-r=-1.64$ p.p. in Czechia). As mentioned, this negative difference has been recorded in all selected regions. Potatoes are a crop which increase the erosion risk [44] especially in highland areas [45]. The possible reasons for lower potatoes shares could be the costs of needed technology, water consumption and the damages caused by pests during production. Thus, producers linger towards more profitable commodities such as corn and rapeseed.

The proportion of sugar beets, as a wide-line crop on sowing areas can contribute to erosion when it is grown in inappropriate areas. If the agronomical instructions are followed then the sugar beet can be considered for soil quality improving crops, especially if strip tillage is applied [46]. The share of sugar beet growing has been slightly decreasing $(R-r=-0.37$ p.p.). Recently, sugar beets have been used more for bioethanol production.

The share of permanent grassland (31.58\% of total observed area in Czechia) is higher than the normative value (+12.97 p.p.) throughout the whole LPIS. Increasing area of grassland has no negative impact on the soil quality. Permanent grasslands support water retention on land and prevent soil degradation by erosion [47].

According to CSO data [28] only three crops-wheat, barley, and rapeseed-are grown on more than $63 \%$ of sowing areas. Farmers' practices are influenced by the market demand and profitability of cultivated commodities. This trend was also illustrated by an increasing Herfindahl-Hirschman Index value (Figure 3). The main advantage of HHI lies on its ability to include many crops within a region while allowing for the impact of each individual crops market share on the calculation [48]. The results suggest decreasing diversity in all observed regions. The HHI value for Czechia is around 2000. According to [32], the segment with an HHI score of less than 1000 is not considered to be concentrated. Those segments with an HHI score between 1000 and 1800 are moderately concentrated, while segments over 1800 are viewed as concentrated, and values between 1800 and 2750 indicate high concentration. Reference [49] indicate the values lower than 1500 as an unconcentrated segment. Data shows that the highest decrease of crop diversity was recorded in Moravian-Siliesian region $(\mathrm{HHI}=2712)$, followed by Zlín $(\mathrm{HHI}=2387)$, and South Moravia $(\mathrm{HHI}=2188)$. These regions are above the Czech Average (HHI = 2013). The lower values were recorded in Central Bohemia $(\mathrm{HHI}=2009)$ and the Olomoc $(\mathrm{HHI}=1893)$ regions. 
The result is a narrow crop composition where cereals and rapeseed dominate. Reference [50] argues that due to the low crop diversity the crop rotation is disrupted. In addition, the so-called soil fatigue may occur if crop rotation principles are not followed. The soil is then temporarily unsuitable for the same or related types of crops [51].

Many farmers support the idea that crop rotation can be fully replaced by chemigation. As a result, in $90 \%$ of the sowing areas, winter rapeseed is grown between two periods when the grains are grown (spring wheat-rapeseed-winter wheat). On one hand, narrowing of crop rotation has an impact on the imbalance of nutrient removal from the soil. In conditions without livestock production, they are not prospective in long-run [52]. On the other hand, Reference [53] elaborates that most farmers try to use the appropriate agro-technical operations in optimal time, no matter the farm size; however, the respondents confirmed that in practice there are cases when this is not possible.

Limited crop rotation (short crop rotation, monoculture) or a high share of cereals in the crop structure changes the species spectrum of weeds (a more distinct occurrence of relatively difficult-to-control, highly competitive weeds). In cases when using minimizing technology, this trend is more intense [50]. The negative impacts on soil in monocultural crop cultivation are confirmed by [54]. In Czechia, rapeseed is grown on $16 \%$ of arable land which places Czechia in the first place, with the highest share in Europe [28].

There is a decrease in sowing areas of Czechia in the extent of growing potatoes and especially perennial fodder plants (Table 2, [28]). Fodder crops are losing their range of use because of the decline in livestock production. However, they could have potential, for example, in the production of biofuels.

The problem of long uninterrupted large fields that fail to contain water is also addressed, for example, by the CAP reform of 2013. Since 2015, there has been a switch to multi-component payment, i.e., including climate-friendly and greening-friendly payments. Greening payments also address the diversification of crops cultivation. A more significant intervention in the sphere of sowing areas in 2018 is not yet clear. Reference [55] also mentions the continuous need of institutional support for small farmers and family farms. Studies also show that farmers would appreciate further government support such as courses focused on the competitiveness of the market [56].

\section{Conclusions and Recommendations}

The objective of this paper is to determine the main factors which may cause the decrease of the official land price in the selected regions. This study is based on a specific approach which uses the official land price as an indicator of the soil fertility and so called "valuation type structure" which indicates the optimal share of crops for given area according to the local conditions. The results contribute to the current discussion about soil protection, changing climatic conditions and its relation to agriculture. The study is quite specific because of the unique data set which is available only in Czechia and Slovakia. This data set allows us to consider the soil quality and related factors. The study places the selected facts and trends into context, however it does not identify the severity of impact of individual factors on soil quality and the official land price. Once one is discussing the soil quality, he or she can easily conclude that there are many factors which influence the soil quality; however, to explore this, further research needs to be conducted.

Based on the results of the statistical analysis, it is possible to conclude that crop structure, which, according to VTS, should bring the highest possible yield by keeping the soil quality at the same level, is not followed in any of the selected regions. Further analysis discovered only one crop in only one region (rapeseed in Moravian-Silesian Region) where the difference between the VTS and real share was not statistically significant at the level $\alpha=0.05$. The results show that that in practice, farmers follow different objectives which do not correspond with good soil management practice. In addition, the Herfindahl-Hirschman Index was calculated for all observed regions and Czechia as a whole. The results confirmed the trend of decreasing crop diversity in selected regions. The HHI values are higher than the Czech average in all selected regions except the Olomouc, and the Central Bohemia Region. The researchers also utilize the Czech Statistical Office data to create a conclusive view of these 
trends in a long-term context. From these analyses, it is obvious that observed trends are common for the whole of Czechia. Their influence is probably the strongest in the selected regions where the soil quality decreased as well as the official land price. The trend of decreasing crop diversity can be observed in other EU countries and should be considered in single area payments scheme (SAPS) rules. But there are some specifics of Czech agricultural sectors, such as the high average area per one farm, or farmers mostly renting land, which cause farmers to follow more short-term goals. Based on that, the following recommendations can be offered considering the addressed issue:

- Crop rotation should not be limited to the main three crops: winter barley-winter rapeseed-winter wheat.

- As part of crop rotation, consider the negative impact of the overlapping share of wheat and maize, and the declining development of sugar beet and perennial fodder crops.

- Encourage growing of perennial fodder crops as part of greening support. Greening could also help the perennial fodder crops cultivation for seeds as a subject of Czech foreign trade.

- The greening part of SAPS requires that the farmers with areas higher than 30 hectares grow at least 3 different crops. However, it would be suitable to monitor the variety representation as the mix of corn, wheat, and rapeseed (as 3 common crops) is not appropriate.

- There is a lack of farm manure in the soil. The remittance of the SAPS payment should be partially linked to the livestock unit per hectare.

Author Contributions: The authors contributed equally to this work. Conceptualization, Z.G. and K.M. (Karel Malec); Formal analysis, K.M. (Karel Malec) and K.M. (Kamil Maitah); Funding acquisition, Z.G., K.M. (Karel Malec), M.M., L.S. and K.M. (Kamil Maitah); Investigation, S.N.K.A.-K. and J.S. (Jitka Sirohi); Methodology, K.M. (Karel Malec) and S.N.K.A.-K. Project administration, M.M. and L.S.; Software, S.N.K.A.-K. and K.M. (Kamil Maitah); Supervision, M.M. and L.S.; Writing-original draft, Z.G., K.M. (Karel Malec) and K.M. (Kamil Maitah); Writing-review \& editing, K.M. (Karel Malec), M.M., S.N.K.A.-K. and J.S. (Jeta Sahatqija). All authors have read and agreed to the published version of the manuscript.

Funding: This paper was supported by the Internal Grant Agency (IGA) of the Faculty of Economics and Management, Czech University of Life Sciences Prague, grant no. 2019B0011 "Economic analysis of water balance of the current agricultural commodities production mix in the Czech Republic" (Ekonomická analýza vodní bilance stávajícího produkčního mixu zemědělských komodit v ČR).

Conflicts of Interest: The authors declare no conflict of interest.

\section{References}

1. Blum, W.E. Functions of soil for society and the environment. Rev. Environ. Sci. Bio Technol. 2005, 4, 75-79. [CrossRef]

2. Desaules, S.; Ammann, P.; Schwab, P. Advances in long-term soil-pollution monitoring of Switzerland. J. Plant Nutr. Soil Sci. 2010, 173, 525-535. [CrossRef]

3. Fließbacha, A.; Oberholzer, H.R.; Gunst, L.; Mader, L. Soul organic matter and biological soil quality indicators after 21 years of organic and conventional farming. Agric. Ecosyst. Environ. 2007, 118, 273-284. [CrossRef]

4. Arshard, M.A.; Martin, S. Identifying critical limits for soil quality indicators in agro-ecosystems. Agric. Ecosyst. Environ. 2002, 88, 153-160. [CrossRef]

5. Obade, V.P. Integrating management information with soil quality dynamics to monitor agricultural productivity. Sci. Total Environ. 2019, 651, 2036-2043. [CrossRef]

6. Eurostat. Food: From Farm to Fork Statistics. 2011. Available online: http://epp.eurostat.ec.europa.eu/ statistics_explained/index.php/From_farm_to_fork_food_chain_statistics (accessed on 18 February 2019).

7. Drobnik, T.; Grenier, L.; Keller, A.; Regamey, A. Soil quality indicators-From soil functions to ecosystem services. Ecol. Indic. 2018, 94, 151-169. [CrossRef]

8. Lambin, E.F.; Rounsevell, M.D.A.; Geist, H.J. Are agricultural land-use models able to predict changes $\mathrm{n}$ land-use intensity? Agric. Ecosyst. Environ. 2000, 82, 321-331. [CrossRef]

9. MoA. Zpráva o stavu zemědělství za rok 2016; Ministry of Agriculture Czechia: Prague, Czech Republic, 2017.

10. Šnobl, J.; Pulkrábek, J. Basics of Plant Production, 1st ed.; Czech University of Life and Sciences Prague: Prague, Czech Republic, 2010; pp. 1-174. 
11. Wischmeier, W.H.; Smith, D.D. Prediciting Rainfall Erosion Losses: A Guide to Conservation Planning; United States Department of Agriculture: Washington, DC, USA, 1978; Volume 53, pp. 537-587.

12. Šoltysová, B.A.; Kotorová, D. Zmeny pôdnych vlastností vplyvom pestovatel'ského systému. Res. Inst. Soil Sci. Soil Prot. 2008, 9, 27-28.

13. Czech Statistical Office. The Sowing Areas Evolution. 2012. Available online: https://www.czso.cz/ documents/10180/20534292/sk1072612analyza.pdf/7a69c2d7-d497-4cef-82a1-efa8a4f00d28?version=1.0 (accessed on 9 February 2019).

14. Jones, R.J.A.; Houškova, B.; Bullock, P.; Montanarella, L. Soil Resources of Europe, 2nd ed.; European Soil Bureau Institute for Environment \& Sustainability JRC: Ispra, Italy, 2005; pp. 4-433.

15. Vopravil, J.; Podrázský, V.; Batysta, M.; Novák, P.; Havelková, L.; Hrabalíková, M. Identification of agricultural soils suitable for afforestation in the Czechia using soil databse. J. For. Sci. 2015, 61, 141-147. [CrossRef]

16. Voltr, V. Assessment of agricultural land fund in the Czechia, importance and future. Agris. Line 2011, 3, 13-22.

17. BPEJ eCatalogue. Available online: https://bpej.vumop.cz/ (accessed on 18 November 2019).

18. Soukal, I.; Tarnowska, A. Agricultural land prices development in the Czechia and the latest legal development. In Proceedings of the Vision 2020: Sustainable Economiv Development, Innovation Management, and Global Growth, Madrid, Spain, 8-9 November 2017; ISBN 978-0-9860419-9-0.

19. Němec, J. Evaluation And Appraisement Of Agricultural Land In The Czechia. Bonitace A OceňováníZemědělskéPridy $\check{C} R$; Institute of Agricultural Economics and Information: Prague, Czech Republic, 2001; ISBN 80-85898-90-X.

20. Minitry of Agriculture. Report on the State of Agriculture of the Czechia; Ministry of Agriculture of the Czechia: Prague, Czech Republic, 2012.

21. Ministry of Finance. Public Notice: Cadastral Parcels with Official Land Prices as Amended; Ministry of Finance of the Czechia: Prague, Czech Republic, 2017.

22. Gelbeltova, K.; Malec, K. Analysis of selected factors affecting official land prices in Czech agriculture (2009-2018). In Proceedings of the Agrarian Perspectives XXVII, Prague, Czech Republic, 19-20 September 2018; pp. 51-57, ISBN 978-80-213-2890-7.

23. Soliwoda, M.; Spicka, J.; Vihelm, V.; Pawłowska-Tyszko, J.; Gorzelak, A. Is there a relationship between the prevailing model of agriculture and the structure of the crop and livestock insurance markets? A comparison between the Czechia and Poland. Stud. Agric. Econ. 2017, 119, 77-84. [CrossRef]

24. Kotyza, P.; Hornowski, A. Does size matters for creating income and value added? Case study of individual farmers in the Czechia and Poland using FADN data. In Proceedings of the Agrarian Perspectives XXVI, Prague, Czech Republic, 13-15 September 2017; pp. 116-122, ISBN 978-80-213-2787-0.

25. Hlavinka, P.; Kersebaum, C.K.; Dubrovsky, M.; Fischer, M.; Pohankova, E.; Balek, E.; Zalud, Z.; Trnka, M. Water balance, drought stress and yields for rainfed field crop rotations under present and future conditions in the Czechia. Inter. Res. Sci. Publ. 2015, 65, 175-192.

26. Edwards, J.H.; Wood, C.W.; Thurlow, D.L.; Ruf, M.E. Tillage and Crop Rotation Effects on Fertility Status of a Hapludult Soil. Soil Sci. Soc. Am. J. 1992, 56, 1577-1582. [CrossRef]

27. LPIS, User Guide; Ministry of Agriculture: Prague, Czech Republic, 2018.

28. Czech Statistical Office. Public Database. 2018. Available online: https://vdb.czso.cz/vdbvo2/faces/index.jsf? page $=$ statistiky \&\&katalog=30840\&\&akt (accessed on 6 October 2018).

29. Voltr, V.; Hruška, M.; Šařec, P.; Leština, J.; Froněk, P. Methodology of Land Valuation for Evaluated Soil Ecological Units (ESEU); Certified Method.: Methodology of Land Valuation for Evaluated Soil Ecological Units (ESEU); Certified Method.: Metodika ocenění půdy pro bonitované půdně-ekologické jednotky (BPEJ); Certifikovaná metodika; Institute of Agricultural Economics and Information (IAEI): Prague, Czech Republic, 2007-2011. Available online: https://www.uzei.cz/data/usr_001_cz_soubory/metodika_oceneni_bpej.pdf (accessed on 7 January 2020).

30. Klečka, M. Bonitace čs. zemědělských půd a směry jejich využití, User Manual, Prague and Bratislava; Ministry of Agriculture and Food: Prague, Czech Republic, 1984.

31. Pearson, K. On the criterion that a give system of deviations from the probable in the case o a correlated system of variables in such that it can be reasonably supposed ot have arisen from random sampling. Philos. Mag. Ser. 1990, 5, 157-175.

32. Calkins, S. The new merger guidelanises and the Herfindahl-Hirschman Index. Calif. Law Rev. 1983, 71, 402-429. [CrossRef] 
33. Němeček, J.; Mülhanselová, M.; Macku, J.; Vokoun, J.; Vavříček, D.; Novák, P.T. Taxonomický Klasifikační Systém puid České Republiky, 1st ed.; Czech University of Life and Sciences Prague: Prague, Czech Republic, 2011; pp. 2-95.

34. Makowski, L.; Ostroy, J. Perfect Competition and the Creativity of the Market. J. Econ. Lit. 2001, 2, 479-535. [CrossRef]

35. Porcelli, C.; Gutierrez, F.H.; Lavado, R. The K/Na and $\mathrm{Ca} / \mathrm{Na}$ rations and rapeseed yield, under soil salinity or sodicity. Plant Soil 1995, 175, 251-255. [CrossRef]

36. Procházkova, B.; Dovrtěl, J.; Dryšlová, T.; Křen, J.; Lukas, V.; Neudert, L.; Smutný, V.; Winkler, J. Význam A Možnosti Optim. Struktury A Stř́idání Plodin V Systémech Hospodaření Na Půdě. Uplatněná Certifikovaná Metod. Mendel Univ. Brno 2011, 5, 15-35.

37. SPZO Czech Union of Growes and Processors of Oilseeds of the Czechia. 2018. Available online: http://www.akcr. cz/txt/myty-a-fakta-o-pestovani-a-zpracovani-repky-olejky-v-cr-brozura (accessed on 20 January 2019).

38. Kang, G.; Beri, V.; Sidhu, B.; Rupela, O. A new index to assses soil quality and sustainability of wheat-based cropping systems. Biol. Fertil. Soils 2005, 41, 389-398. [CrossRef]

39. McGregor, K.C.; Mutchler, C.K.; Romkens, M.J.M. Effects of tilage with different crop residues on runoff and soil loss. Trans. Am. Soc. Agric. Eng. 1990, 33, 1551-1556. [CrossRef]

40. Institute of Agricultural Economics and Information (IAEI). Zpráva o stavu zemědělství za rok 2014; IAEI: Prague, Czech Republic, 2015. Available online: http://eagri.cz/public/web/mze/ministerstvo-zemedelstvi/vyrocni-ahodnotici-zpravy/zpravy-o-stavu-zemedelstvi/zelena-zprava-2014.html (accessed on 7 January 2020).

41. Kadlec, V.; Dostál, T.; Vrána, K.; Kavka, P.; Krása, P.; Devátý, J.; Podhrázská, J. Navrhování Technických Protierozních Opatření: Metodika, 1st ed.; Research Institute for Soil and Water Conservation: Prague, Czech Republic, 2014.

42. Phan Ha, H.A.; Huon, S.; Henry des, T.; Orange, D.; Jouquet, P.; Valentin, C.; De Rouw, A.; Duc Tran, T. Impact of fodder cover on runoff and soul erosion at plot scale in a cultivated catchment of North Vietnam. Geoderma 2012, 177, 8-17. [CrossRef]

43. Kotyza, P.; Slaboch, J. Food Self Sufficiency in Selected Crops in The Czech Republic and Poland. Acta Univ. Agric. Silvic. Mendel. Brun. 2014, 62, 1329-1341. [CrossRef]

44. Bug, J.; Mosimann, T. Rill Erosion in Lower Sacony-Results of an 11-yeat survet on the expansion, small-scale distribution and cause of soil erosion. Bondekultur 2012, 63, 63-75.

45. Evans, R. Factors controlling soil erosion and runoff and their impacts in the upper Wissey catchment, Norfolk, Englad: A ten year monitoring programme. Earch Surf. Proceses Landf. 2017, 42, 2266-2279. [CrossRef]

46. Laufer, D.; Loibl, B.; Märländer, B. Soil erosion and surface runoff under strip tillage for sugar beet (Beta vulgaris L.) in Central Europe. Soul Tillage Res. 2016, 162, 1-7. [CrossRef]

47. Ajayi, A.E.; Horn, R. Transformation of ex-arabe land to permanent grassland prompotes pore rigidity and mechanical soil resilience. Ecol. Eng. 2016, 94, 592-598. [CrossRef]

48. Albarran, A.B.; Dimmick, J. Concentration and economics of multuformity in the communication industries. J. Media Exonomics 1996, 9, 41-50. [CrossRef]

49. Bates, B.J. Concentration local television markets. J. Media Econ. 1993, 3, 3-22. [CrossRef]

50. Agromanual.cz. 2016. Available online: https://www.agromanual.cz/cz/clanky/ochrana-rostlin-a-pestovani/ plevele/plevele-v-ozime-psenici-a-zpusoby-jejiho-pestovani (accessed on 3 February 2019).

51. Malicki, L.; Nowicki, J.; Szwejkowskib, Z. Soil and crop responses to soil tillage systems: A Polish perspective. Soul Tillage Res. 1997, 43, 65-80. [CrossRef]

52. Kulovaná, E. Rehabilitujme význam osevního postupu pro pěstování ozimé řepky. Uroda. 2001. Available online: https://www.uroda.cz/rehabilitujme-vyznam-osevniho-postupu-pro-pestovani-ozimerepky/ (accessed on 5 December 2018).

53. Prus, P. The role of higher education in promoting sustainable agriculture, corporate social responsibility and business ethics in the central and Eastern Europe. Nomos Verl. Mbh Co. Kg. J. East Eur. Manag. Stud. (JEEMS) 2019, 99-119. [CrossRef]

54. Středová, H.; Středa, T.; Chuchma, F.; Rožnovský, J. Vhodnost'pol'nohospodárskych pôd a krajiny Slovenska na pestovanie rastlín. Czech Univ. Life Sci. Prague 2016, 4, 94-119. 
55. Prus, P. Farmers' opinions about the prospects of family farming development in Poland. In Proceedings of the 2018 International Scientific Conference Economic Science for Rural Development, Jelgava, Latvia, 9-11 May 2018; Volume 47, pp. 267-274. [CrossRef]

56. Prus, P.; Drzazdzynska, K. Farmers' assessment of training services and the impact of agricultural advisory on selected developmental factors affecting farming. In Proceedings of the 2017 International Scientific Conference Economic Science for Rural Development, Jelgava, Latvia, 27-28 April 2017; Volume 44, pp. 338-344.

(C) 2020 by the authors. Licensee MDPI, Basel, Switzerland. This article is an open access article distributed under the terms and conditions of the Creative Commons Attribution (CC BY) license (http://creativecommons.org/licenses/by/4.0/). 